\title{
THE POWER OF APPOINTMENT: TOOL OF ESTATE PLANNING AND DRAFTING*
}

\author{
W. BRYAN BOLICH†
}

\section{INTRODUCTION}

$T$ HE ARTIST who paints a landscape has at his disposal all the colors of the spectrum, but the lawyer who drafts a dispositive instrument has available only a limited number of fixed types of present and future estates and other interests in property, legal or equitable. These are the chips with which the game of conveyancing is played, and, as to function, they may be roughly divided into family interests and commercial interests. They include the fee simple, the term of years, the reversion, the life estate, and the remainder. The first three are largely commercial, while the life estate and remainder are entirely noncommercial and of great utility in family settlements of property, especially those which seek to provide for more than one generation. The most sophisticated branch of the common law, the law of property with its concepts of temporally divided ownership, the trust, and the power of appointment, affords great flexibility of disposition, although in a number of situations at the price of considerable constructional uncertainty and legal technicality. ${ }^{1}$ This article will discuss certain nontax aspects of the third member of this legal trinity, the power of appointment, concerning what it is, why to use it, and how to use it, primarily from the standpoint of the estate planner and draftsman.

It has been said that "the power of appointment is the most efficient dispositive device that the ingenuity of Anglo-American lawyers has ever worked out."'2 However, like most interesting things, it has a past, and this past is such that the present-day lawyer cannot be unmindful of it. Except by special custom in certain localities,

- This article in substance reproduces a paper by the author presented to the North Carolina Bar Association Institute on the Nontax Aspccts of Estate Planning held April 19-20, 1963, in Winston-Salem, North Carolina.

†A.B. 1917, 1920-1921, Duke University; B.A. (Juris.) 1923, B.C.L. 1924, M.A. 1928, Oxford University. Member, North Carolina Bar. Professor of Law, Duke University.

${ }^{I}$ See Hargreaves, Modern Real Property, 19 Modern L. Rev. 14 (1956).

2 Leach, Powers of Appointment, 24 A.B.A.J. 807 (1938). 
it was impossible under English law to devise a legal freehold unti] the Statute of Wills $(1540) .^{3}$ It was possible, however, for a landowner to circumvent this disability by resort to a use coupled with a power of appointment. For example, $A$, the fee simple owner, by an inter vivos conveyance could transfer his land to $B$ in fee simple to the use of such persons as he, $A$, should by will appoint, and in default of and until such appointment, to the use of $A$ and his heirs. Prior to the Statute of Uses $(1536),{ }^{4} B$ held legal title for $A$ 's use and benefit. When $A$ died leaving a will appointing the property, legal title was still in $B$, but as feoffee to uses, $B$ was under a duty to convey to the persons named in $A$ 's will which the court of chancery would enforce. In theory, $A$ 's appointees took by way of shifting use on an event named in $A$ 's original conveyance to $B$, namely the exercise by $A$ of his testamentary power of appointment. Thus, the title passed not by $A$ 's will but by $A$ 's inter vivos conveyance.

This probable original function of the power of appointment and the legal theory then necessary for its operation are of fundamental importance to us today, for these two factors established the orthodox common law theory that the exercise of the power is the event upon which the title shifts, not the conveyance, and title thus passes from the donor to the appointee. If $T$ devises property to $A$ for life, remainder to such persons as $A$ shall appoint, and $A$ appoints to $B, B$ takes title from $T$, not from $A$. The appointment is said to relate back to the creation of the power and to operate as if $A$ had filled in a blank in $T$ 's will..$^{5}$ Current American law regarding powers of appointment is the outgrowth of a fundamental acceptance of the relation back doctrine, ${ }^{6}$ subject to important exceptions where the proprietary aspect of the power of appointment is most apparent, such as the general power presently exercisable, which is in essence ownership. ${ }^{7}$

\footnotetext{
${ }^{3} 32$ Hen. 8 , c. 1.

127 Hen. 8 , c. 10.

- Dant v. Fidelity \& Columbia Trust Co., 302 Ky. 54, 193 S.W.2d 399 (1946); HogarthSwann v. Weed, 274 Mass. 125, I74 N.E. 314 (1931); Matter of Harbeck, 161 N.Y. 211, 55 N.E. 850 (1900); Chewning v. Eason, 158 N.C. 578,74 S.E. 357 (1912); Commonwealth v. Williams' Ex'rs, 13 Pa. 29 (1850); Commonwealth v. Duffield, $12 \mathrm{~Pa} .277$ (1849).

- Central Hanover Bank \& Trust Co. v. Wolf, 35 N.Y.S.2d 148 (Sup. Ct. 1942); City Bank Farmers Trust Co. v. Green, 160 Misc. 370, 289 N.Y. Supp. 473 (Sup. Ct. 1936); 3 Powelr, Resl Property, I 387 (1952) [hereinafter cited as Poweln]; Simes, The Devolution of Title to Appointed Property, 22 luL. L. REv. 480 (1928).

7 Jones v. Clifton, 101 U.S. 225 (1879); Matter of Hicks, 173 Misc. 91, 18 N.Y.S.2d
} 
The power of appointment thus carries the dust of five centuries or more of Anglo-American law. Although the English Statute of Wills largely obviated the earlier testamentary function of the power of appointment, its flexibility and maneuverability made it a conveyancer's favorite, especially with the advent of strict family settlements. Thus, it was used to circumvent certain disabilities of married women relating to the ownership and conveyance of their property, ${ }^{8}$ to escape dower and curtesy, ${ }^{9}$ and to avoid or lessen certain burdens of feudal tenure, including relief and primer seisin, the death taxes of the feudal era.

In the United States prior to 1900 , there was hardly a law of powers of appointment. With considerable reliance upon English common law, the Restatement of Property, adopted in 1938, gave the bar its first complete and systematic American presentation of the subject. Today there are great gaps yet to be filled in the law of most states before anything like a complete American law of powers can exist. In North Carolina, for example, lawyers of the landed gentry of pre-Civil War days seem to have made considerable use of powers of appointment, but after 1865 the practice declined, and litigation concerning common law powers of appointment is still not great. In order to develop such a body of law there must be accumulated wealth to be disposed of, conveyancing lawyers alert to the potentialities of the power, and significant relative advantages in comparison with other available dispositive devices. In estate planning and drafting, it is, in combination with successive estates, the tool par excellence for the avoidance or minimization of estate taxes, ${ }^{10}$ and by no other legal concept can such flexibility be imparted to property settlements. ${ }^{11}$ There is considerable case law and some statutes upon which the North Carolina lawyer can rely, and

182 (Surr. Ct. 1939); Rogers v. Hinton, 62 N.C. 101 (1867). See McDougal, Future Interests Restated: Tradition versus Clarification and Reform, $55 \mathrm{HARv}$. L. REv. 1077, 1104-15 (1942), for a critique of the Restatement of Property's general acceptance of the dogma of relation back.

${ }^{B}$ Young v. Sheldon, 139 Ala. 444, 36 So. 27 (1904); Norfleet v. Hawkins, 93 N.C. 392 (1885).

- Matter of Davies, 124 Misc. 541, 209 N.Y. Supp. 296 (Surr. Ct.), aff'd, 215 App. Div. 750, 212 N.Y. Supp. 796 (1925), aff'd, 242 N.Y. 196, 151 N.E. 205 (1926); Barr v. Howell, 85 Misc. 330, 147 N.Y. Supp. 483 (Sup. Ct. 1914); Ray v. Pung, 5 B. \& Ald. 561, 106 Eng. Rep. 1296 (K.B. 1822).

${ }^{10}$ See Lowndes \& Kramer, Federal. Estate and Gift Taxes $\$ 41.3$ (2d ed. 1962); Lowndes, Estate Planning and Powers of Appointment, 30 N.C.L. REv. 225 (1952).

11 Restatement, Property, introductory note to $\$ \$ 318.69$ (1940), discusses the functions of powers of appointment. 
the texts and leading cases from other jurisdictions afford sufficient guidance for the intelligent use of the power of appointment along common law lines. Where uncertainties still remain, expert drafting can eliminate most of them. ${ }^{12}$

The Power of Appointment Concept and Its Terminology

The Restatement of Property defines the power of appointment as "a power created or reserved by a person (the donor) having property subject to his disposition enabling the donee of the power, within such limits as the donor may prescribe, to designate the transferees of the property or the shares in which the property shall be received."13 Essentially it is a discretionary power with relation to specific property, apart from any ownership thereof, to specify the appointees or their shares of ownership in the property. This definition expressly excludes powers of sale, powers of attorney, a power to revoke a trust, and a trustee's discretionary power to augment income out of principal or to sprinkle income or principal among a group of beneficiaries. However, it must be remembered that these are property concepts, some of which are treated as powers of appointment for tax and other purposes. In reality, one might say there are four general classifications of powers: (1) common law, ${ }^{14}$ (2) Restatement of Property, ${ }^{15}$ (3) state statutory, ${ }^{16}$ and (4) federal estate tax. ${ }^{17}$ In estate planning and drafting, a lack of awareness of what fact situations may be legally classified as powers of appointment and how they operate can result in unintended creation or exercise with adverse results. For example, a trustee's discretionary power to sprinkle income or principal among trust beneficiaries is treated as a power of appointment, ${ }^{18}$ and a conveyance of land to $A$ for life, remainder as he shall appoint, with a gift to $A$ 's heirs in default of

12 See generally Casner, Estate Planning-Powers of Appointment, 64 Harv. L. REv. 185 (1950); Fleming, Provisions for Trusts and Powers of Appointment, 1950 U. ILL. L.F. 341; Halbach, The Use of Powers of Appointment in Estate Planning, 45 Iowa L. REv. 691 (1960); Leach, supra note 2; Stephenson, Powers of Appointment, 29 TRUST BULL. 21 (1950).

13 Restatemient, Property $\S 318$ (1940).

14 SMms \& SMrth, Future INTERESTS $\$ 872$ (2d ed. 1956) [hereinafter cited as Simes \& SMITH].

15 Restatement, Property $§ \S 318-69$ (1940).

${ }^{10}$ The outstanding example is N.Y. REAL Prop. LAw $\$ 5$.

${ }^{17}$ INT. REv. CODE OF 1954, § 2041.

${ }^{18}$ See notes 166,167 infra. 
appointment might attract the Rule in Shelley's Case if $A$ appoints the remainder to his heirs or does not exercise the power. ${ }^{10}$

As a matter of terminology, the law of powers has its accepted definitions. The creator of the power is the donor; the recipient of the power is the donee. The persons to whom or for whom the appointment may be made are the objects of the power, and persons outside this class are known as strangers to the power. The person to or for whom an appointment is made is the appointee, and the person who is to receive the property in default of effective appointment is the taker in default. The property subject to appointment is the appointive property, and the making of an appointment by the donee is called its exercise. ${ }^{20}$

\section{II}

\section{Agsolute Interest in Donee Versus Limited Estate and Power of Appointment}

The beneficial absolute owner of property has as an incident thereof certain wide powers of disposition. The magic of the power of appointment enables such an owner to confer these powers of disposition in the form of a power of appointment upon either a nonowner or a limited owner of this property and thereby make him, in practical effect, the absolute owner. Thus, if the owner conveys property to $A$ for life and at $A$ 's death to such person or persons as $A$ shall appoint by will, although $A$ 's ownership terminates at his death, his power of appointment enables him to dispose of the property by will as he sees fit. If, on the other hand, the fee simple owner transfers his estate to $A$, rules regarding restraints on alienation prevent him from withholding from $A$ such incidents as the freedom to transfer by deed or will or to have the property pass by intestate succession..$^{21}$ As stated above, such limitations may in effect be accomplished, however, by conveying to $A$ a limited estate with a power of appointment in fee, by virtue of which $A$ may be given the principal powers and prerogatives of fee simple ownership without all the incidents thereof. Except as provided by some statutes,

\footnotetext{
${ }^{19}$ Heid v. Fortunato, I5 Del. Ch. 367, I38 Atl. 606 (Ch. 1927); Cushing v. Blake, 30 N.J. Eq. 689 (Ct. Err. \& App. 1879); Restatement, Property § 312, comment $i$ (1940). But cf. Patrick v. Morehead, 85 N.C. 62 (1881).

20 Restatement, Property § 319 (1940).

21 Payne v. Hart, 178 Ark. 100, 9 S.W.2d 1059 (1928); Gray v. Gray, 300 Ky. 265, 188 S.W.2d 440 (1945); Andrews v. Hall, 156 Neb. 817, 58 N.W.2d 20I (1953); Soper v Melford, 258 S.W.2d 118 (Tex. Civ. App. 1953); Restatement, Property $\$ 406$ (1944)
} 
this will not enlarge such estate into a fee or expose the limited owner to all of its burdensome incidents. ${ }^{22}$ However, because of the general prevalence of fee simple presumption statutes, great care must be taken to create an express life estate coupled with such a power and a valid remainder in default of appointment. ${ }^{23}$ If there is a general devise with an attempted gift over of what remains undisposed of by the first taker, such a gift over is generally held invalid because it prevents devolution of the fee simple by intestacy. ${ }^{24}$ However, some cases and statutes cause such a limitation to create a life estate with a power to appoint the remainder in fee. ${ }^{25}$

III

\section{Kinds of Powers of Appointment}

Common law powers of appointment are classified in a number of ways, but only two of these classifications are generally involved in the drafting of wills and trusts. These are the manner in which a power can be exercised and the scope of the power granted. As to manner of exercise, this may be done by deed, by will, or by either deed or will. The Restatement defines the power to appoint by will only as a testamentary power, while the other two are classified as powers presently exercisable. ${ }^{26}$ As to scope, the $R e$ statement classifies powers as general and special. A power is general if it can be exercised wholly in favor of the donee or his estate. It is special if it can be exercised only in favor of persons other than the donee and if the donor has not manifested an intent to create or reserve the power primarily for the donee's benefit. ${ }^{27}$ However, these four groupings according to manner of exercise and scope will not accomodate all powers of appointment. For example,

${ }^{22}$ Rudisell v. Hoyle, 254 N.C. 33, 118 S.E.2d 145 (1961); Hardee v. Rivers, 228 N.C. 66, 44 S.E.2d 476 (1947); Chewning v. Eason, 158 N.C. 578, 74 S.E. 357 (1912); Long v. Waldraven, 113 N.C. 337, 18 S.E. 251 (1893); Restatement, Property $\$ 111$ (1936, Supp. 1948).

${ }_{23} 2$ Powell If 184 n.64 (1950); Restatement, Property \$ 39 (1936, Supp. 1948). See also N.C. GEN. STaT. \$ 39-1 (1950); Alexander v. Cunningham, 27 N.C. 430 (1845) (antedates the statute).

24 Tarbell v. Smith, 125 Iowa 388, 101 N.W. 118 (1904); Basnight v. Dill, 256 N.C. 474, 124 S.E.2d 159 (1962); Burgess v. Simpson, 224 N.C. 102, 29 S.E.2d 38 (1944); Heefner v. Thornton, 216 N.C. 702, 6 S.E.2d 506 (1939); Moore v. Holbrook, 175 Va. 471, 9 S.E.2d 447 (1940). But see Hoskins v. May, 213 N.C. 795, 197 S.E. 689 (1938).

${ }^{26}$ Merrill v. Pardun, 125 Neb. 701, 251 N.W. 834 (1933); Chesnut v. Chesnut, 300 Pa. 146, 151 AtI. 399 (1930); N.Y. ReAL Prop. LAW $\$ 57$.

20 Restatement, Property \$ 321 (1940)

${ }^{27}$ Id. $\$ 320$. 
a power to appoint to anyone except the donee or his estate is neither general nor special, and the power in a donee aged twenty-five to appoint by deed when he attains age thirty is neither presently exercisable nor testamentary. Such powers are fairly numerous and are classified as hybrid powers. ${ }^{28}$

Another common law classification of powers of appointment, which the Restatement expressly refuses to recognize, ${ }^{20}$ is based upon the proprietary interest of the donee in the appointive property. Under this classification powers are either appendant or appurtenant, in gross, or simply collateral. If the donee has an interest in the property which is affected by his exercise of the power, an appendant. or appurtenant power is involved, e.g., to $A$ for life, with power to appoint in fee by deed, and $A$ conveys the possessory estate in fee simple to $B .^{30}$ If the donee's interest is not so affected by an exercise, the power is in gross, e.g., to $A$ for life, remainder as he shall appoint by will; ${ }^{31}$ and if the donee owns no interest in the property, the power is simply collateral, e.g., to $A$ for life, remainder as $B$ shall appoint. ${ }^{32}$ While powers appendant to a limited estate are valid and useful today, a power of appointment appendant to a fee simple seems anomalous and of questionable utility; and though it was valid by English common law, modern American cases generally hold that when such a power is attached to a fee simple estate, it is either void or merges with the donee's estate. ${ }^{33}$ The Restatement takes the position that every power of appointment is void to the extent that its exercise divests a beneficial interest owned by the donee, e.g., property is conveyed to $A$ for life, remainder as $A$ shall appoint. The rationale is that the power exists exclusively over the remainder and not over the life estate. This is contrary to the old common law theory but strictly true analytically because the life tenant has two interests, a life estate and a power of appointment. ${ }^{34}$ Powell states that the power appendant as to a fee still exists in some juris-

\footnotetext{
${ }^{28}$ United States Trust Co. v. Montclair Trust Co., 133 N.J. Eq. 579, 33 A.2d 901 (Ch. 1943); Restatement, Property $\$ 321$, comment $d$ (1940). See Gold, The classifica. tion of Some Powers of Appointment, 40 MicH. L. REv. 337 (1942).

29 Restatement, Property $\$ 318$, comment $c$ (1940); id. $\$ 325$, comment $a$.

${ }^{30}$ Troy v. Troy, 60 N.C. 624 (1864).

31 See Norfleet v. Hawkins, 93 N.C. 392 (1885).

32 Smith v. Garey, 22 N.C. 42 (1838).

so Tillett v. Nixon, 180 N.C. 195, 104 S.E. 352 (1920); Browning v. Bluegrass Hard. ware Co., 153 Va. 20, 149 S.E. 497 (1929).

st Restatement, Property $\$ 325$ (1940).
} 
dictions and may be used when necessary to evade present-day archaic restraints on married women as to contracts and conveyances of their separate property. ${ }^{35}$

\section{IV}

Some Reasons for the Use of Powers of Appointment

When it is desired to arrange for one's property to be enjoyed by more than one generation, the power of appointment seems to be the most efficient method by which one may so control the devolution of his property as to avoid the normal risks of improvident loss by his beneficiaries and at the same time preserve flexibility of disposition and achieve increased technical freedom in long-term property settlements. ${ }^{36}$ The estate planner and draftsman, however, must carefully weigh the pros and cons in each case as to both the question of whether a power should be created or whether an existent power should be exercised in the light of the persons and property involved and certain rules of substantive law which bulk large concerning both the creation and exercise of powers. Some of the reasons why a power of appointment may be effectively used include:

(1) Uncertainty of the future. The power of appointment imparts a needed element of elasticity in the settlement of the average estate. For example, assume that $T$ has a wife and three children, $A, B$, and $C$. If $T$ consulted an attorney about planning his estate and drafting the necessary dispositive instruments, including a will, $T$ would probably express only the general desire that his wife have his property for her life and that his children receive it in equal shares at her death. The attorney's legal experience and knowledge of such matters would immediately suggest some of the probable future contingencies. For example, $T$ 's wife may predecease him; more children may be born; some may predecease $T$, and others may predecease his wife if she outlives him; one or more of such children may leave issue or a widow or both; child $A$ may make a million, $B$ may marry a million, and $C$ may become mentally or

\footnotetext{
${ }^{86}$ See 3 Powell I 388 (1952), where the author concludes that the Restatement's "recognition of the death of powers appendant was a trifle premature." See also Norfleet v. Hawkins, 93 N.C. 392 (1885); Levy v. Griffis, 65 N.C. 236 (1871).

${ }^{30}$ Stephenson, Drafting Wills and Trust Agreenents: Dispositive Provisions $\$ \S$ 4.3, 4.4 (1955) [hereinafter cited as STEPHENSON] presents some fifteen nontax reasons for utilizing powers of appointment in estate planning.
} 
physically a cripple. Under these circumstances, equality of shares would be a poor distribution. Moreover, family changes are not the only factors which $T$ must consider. Other uncertainties, including ever changing social, political, legal, and economic conditions, must be borne in mind. By using a power of appointment of sufficient flexibility and duration so that ultimate disposition is left to the discretion of the donee, $T$ may avoid a too rigid plan of disposition, lessen the necessity for including alternative beneficiaries and complicated contingency provisions in his will, and postpone final settlement of his estate until many years after his death. In his will Lord Mansfield put the matter succinctly:

Those who are nearest and dearest to me best know how to manage and improve, and ultimately in their turn to divide and subdivide, the good things of this world which I commit to their care, according to events and contingencies which it is impossible for me to foresee, or trace through all the mazy labyrinths of time and chance. ${ }^{37}$

(2) The human element: mother and children. The will of Robert Young, who was killed in the Civil War, seems to provide a good example of planning which recognized this factor. It said: "To my beloved wife I give all my estate, real, personal and mixed, to be managed by her (and that she may be enabled the better to control and manage our children), to be disposed by her to them in that manner she may think best for their good and her own happiness." ${ }^{38}$ It was held that the widow was trustee of this estate for herself and her children, with power to appoint the principal to them as she saw fit. To the contention of the children that they were absolutely entitled to the property at age twenty-one, the court declared:

And by the good of the children, he did not mean their pecuniary advancement only or mainly; but their moral, mental and religious training and their filial duty and subjection.... It is true, the mother's control over, and duties to the child, do in one sense partly cease at the child's majority; but it is equally true, that just then the child's filial duties to the mother begin afresh, and ever grow and grow, as he goes forward to manhood and she backward to childhood. ${ }^{39}$

Thus, it would seem that a power of disappointment in the widow might greatly aid in the rearing of the children and the happiness of

\footnotetext{
373 Campbely, Lives of the Chief Justices of ENGLANd 470 (Am. ed. 1874)

${ }^{38}$ Young v. Young, 68 N.C. 309, 310 (1873).

as $1 d$. at 314 .
} 
the mother, since an unruly child or a forgetful adult could not with proprietary impunity be unmindful of his mother. However, this case also points out the possibility that as she grows older, the mother will have decreasing capacity of decision, and she may fall under the domination of one of her children who might not be the most deserving member of the family.

(3) Avoidance of probate. "Another important reason for creating a life estate and remainder in property is the avoidance of expenses and the delay and uncertainties incident to the probate of a will at the life tenant's death. This may be assured by a fixed life estate and remainder or an estate by which the life tenant has a power to appoint by deed only, with a remainder over to the extent that the power is not effectively exercised. However, if the life tenant is given a general power of appointment which is either presently exercisable or testamentary and it is exercised by his will, the property may not go directly from the donor to the donee's appointees or the takers in default. It may have to pass through the hands of the donee's executor in order, for example, to effect the transfer or to pay the donee's debts; ${ }^{* 0}$ and if a trust is involved, the property may be subjected to both extra executor's and trustee's fees under this arrangement. ${ }^{41}$ If the orthodox common law theory of powers were applied and the donee's appointment were read back into the donor's deed or will creating the power, there would be but one fee payable under these circumstances. ${ }^{42}$ If the power is general and the trust ends at the life tenant's death, it creates problems as to both the trustee's duties regarding the property and its inclusion in the donee's estate. ${ }^{43}$ The draftsman creating or exercising a power of appointment must obviously be alert to these problems and should explicitly cover the question whether or not the property is to pass through the estate of the donee.

(4) Avoidance of claims of the donee's creditors. As previously stated, it is the basic theory of powers of appointment that a power is not property and the appointee acquires ownership from the donor

¿0 Aultman v. Myers, 239 Iowa 940, 33 N.W.2d 400 (1948); Boston Safe Deposit \& Trust Co. v. Alfred Univ., 339 Mass. 82, 157 N.E.2d 662 (1959); Olney v. Balch, 154 Mass. 318, 28 N.E. 258 (1891).

«1 Matter of Culver, 294 N.Y. 321, 62 N.E.2d 213 (1945).

"Note, 21 N.Y.U.L.Q. REv. 147 (1946).

43 Nossamian, Trust Administration and Taxation $\$ 36.28$ (2d ed. 1961); Schuyler, Some Problems with Powers, 45 ILL. L. REv. 57, 66-71 (1950). 
rather than from the donee.44 Since property ownership is essen. tially an aggregate of controls, however, in some situations the donee's extensive control over the property subject to his power has caused him rather than the donor to be treated as its real owner. ${ }^{45}$ In the case of a general power, if the donee exercises this porver and his own assets are insufficient to pay his debts, his creditors may reach the appointive property under the equitable assets doctrine in preference to any appointee other than a purchaser for value.40 Since a power of appointment is not property but a mere discretionary power, it is the common law rule that the subject property may not be reached by creditors of the donee so long as the power remains unexercised and the donor and donee are not the same person. ${ }^{47}$ It has been said that "the power of a person to appoint an estate to himself is no more property than his power to write a book or sing a song." 48 However, since a general power is in reality a blank check or deed of the property executed by the donor and only awaits the donee's filling in the payee or grantee's name, there is some justification for treating it as the donee's property from the standpoint of his creditors. The Bankruptcy Act provides that an unexercised power which is exercisable for the donee's own benefit passes to his trustee in bankruptcy, ${ }^{40}$ but this provision has been held not to include a general testamentary power. ${ }^{\text {b0 }}$ Some states have by statute changed the common law rule as to creditors of a donee life tenant by making him owner in fee of the property subject to the power. ${ }^{51}$ The special power differs fundamentally from the general power and is considered a fiduciary relation rather than property. Thus, in case of a special power not itself involving a fraudulent conveyance from the donor, the donee's creditors cannot reach the

\footnotetext{
¿ See note 5 supra.

45 See note 7 supra.

40 Restatement, Property $\$ \S 329,330$ (1940); see 3 Powell $\{389$ n.95 (1952) for an excellent collection of cases. See also Leigh v. Smith, 38 N.C. 442 (1844); Smith v. Garey, 22 N.C. 40 (1838).

${ }^{47}$ Gilman v. Bell, 99 Ill. 144 (1881); Quinn v. Tuttle, 104 N.H. 1, 177 A.2d 391 (1962); Leggett v. Doremus, 25 N.J. Eq. 122 (Ch. 1874); Annold v. Southern Pine Lumber Co., 58 Tex. Civ. App. I86, 123 S.W. 1162 (1909).

${ }^{48}$ In re Armstrong, 17 Q.B.D. 521, 531 (1886).

49 Bankruptcy Act $\S 70 \mathrm{a}$, ch. 54I, 30 Stat. 565 (1898) (amended by 66 Stat. 429 (1952), as amended, II U.S.C. $\$ 110 \mathrm{a}$ (1958)).

${ }^{50}$ Forbes v. Snow, 245 Mass. 85, 140 N.E. 418 (1923); Montague v. Silsbee, 218 Mass. 107, 105 N.E. 611 (1914); In re Peck's Estate, 320 Mich. 692, 32 N.W.2d 14 (1948). See also note 91 infra.

ex Restatement, Property $§ 111$ (1936); id. § 327 (1940).
} 
property and thereby benefit a person to whom he could not appoint. ${ }^{62}$

A counsel of caution seems in order here as to creation and exercise of powers. If the donee of a general power has insufficient assets of his own to pay his debts, such a power should never be exercised in favor of a volunteer. If the donor has real concern about the possible debts or other liabilities of his beneficiary, any estate plans might be wrecked if a general power is given to such a beneficiary because it cannot be insulated against the donee's creditors by provisions of the creating instrument..$^{53}$ In states having severe limitations on spendthrift trusts, a discretionary trust may be the best solution. ${ }^{54}$

(5) Avoidance of marital property rights of the donee's spouse. If a donor wants to prevent the spouse of a donee-beneficiary from acquiring some of the subject property contrary to the beneficiary's wishes, he can confer what practically amounts to fee ownership through the use of a life estate and general power of appointment. Relying upon the basic theories that a donee has a mere power and not ownership of the property subject to the power and that upon an appointment title passes from the donor to the appointee, ${ }^{55}$ it is held that such rights as dower, curtesy, inchoate rights in the nature of such interests, or a statutory forced share do not attach to the appointive property, whether the power be general or special, exercised or unexercised. ${ }^{56}$ However, if the donee specifically appoints the property to his own estate, a compulsory forced share statute in favor of the widow who elects against his will might subject the property to her claim. ${ }^{\mathbf{5 7}}$ By statute in many states a subsequent marriage revokes a prior will either entirely or as to the spouse, with certain exceptions including a will exercising a power of

53 Mercantile Trust Co. v. Bergdorf \& Goodman Co., 167 Md. 158, 173 Atl. 31 (1934); Price v. Cherbounier, $103 \mathrm{Md}$. 107, 63 Atl. 209 (1906); Fiduciary Trust Co. v. First Nat'I Bank, 181 N.E.2d 6 (Mass. 1962); Prescott v. Wordell, 319 Mass. 118, 65 N.E.2d 19 (1946); Holt v. Hogan, 58 N.C. 82 (1859). But see United States Trust Co. v. Montclair Trust Co., 133 N.J. Eq. 579, 33 A.2d 901 (Ch. 1943).

${ }^{83}$ State St. Trust Co. v. Kissel, 302 Mass. 328, 19 N.E.2d 25 (1939); Restatement,

Property $\$ 329$ (1940).

t See 2 Scotr, Trusts $\$ 155$ (2d ed. 1956) [hereinafter cited as ScoTr].

EE See note 5 supra.

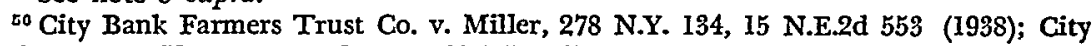
Bank Farmers Trust Co. v. Green, 160 Misc. 370, 289 N.Y. Supp. 473 (Sup. Ct. 1936); In re Kate's Estate, 282 Pa. 417, 128 Atl. 97 (1925); Rsstatement, Property § 332 (1940).

${ }^{67}$ Stmes \&. Smith \$ 947; Restatement, Property \$ 341 (1940). 
appointment unless the appointive property would pass in default of appointment to the testator's heirs. 58

\section{$\mathrm{V}$}

\section{The Creation and Exercise of Powers of Appointment}

\section{A. Creation of Powers}

No particular word formula is required to create a power of appointment. If the instrument which is alleged to create a power of appointment meets the formal requirements for the validity of a deed or will, it may create a power if the donor so intends. ${ }^{60}$ Such a formally sufficient deed or will means an instrument legally valid to create the interest which will arise by the exercise of the power. Thus, an otherwise valid oral lease could not create a power in the lessee to convey a fee simple in the subject land because of the uniform requirement of a signed written instrument to transfer an interest in land. ${ }^{60}$

Since no particular langnage is necessary to create a power, any words sufficiently definite to disclose its nature, the donee, and its objects are sufficient. ${ }^{61}$ A power may also arise by implication. ${ }^{62}$ Assuming that a power has been created, its nature and extent are a matter of construction of the langnage used in the light of the surrounding circumstances. ${ }^{63}$ For example, it has been held that a power to sell does not include a power to mortgage, ${ }^{84}$ but a general power of appointment presently exercisable includes the power to mortgage. ${ }^{65}$

\footnotetext{
${ }^{58}$ N.C. Gen. Stat. $§ \S 31-53$ (Supp. 1961); 6 Powell ף 975 (1958).

${ }^{\circ}$ In re Lidston's Estate, 32 Wash. 2d 408, 202 P.2d 259 (1949); REsTatement, Property § 323 (1940).

${ }^{60}$ Devereux v. McMahon, 108 N.C. 134, 12 S.E. 902 (1891); 6 Powell |ा 881, 894 (1958).

${ }^{61}$ Winchell v. United States, 180 F. Supp. 710 (S.D. Cal.), af'd, 289 F.2d 212 (9th Cir. 1960); Frank v. Frank, 305 Ill. 181, 137 N.E. 151 (1922); Kirkland v. MercantileSafe Deposit \& Trust Co., 218 Md. 17, 145 A.2d 230 (1958); Powell v. Wood, 149 N.C. 235, 62 S.E. 1071 (1908).

o2 Loud v. Poland, 126 Me. 45, 136 Atl. 119 (1927); Bundy v. United States Trust Co., 257 Mass. 72, 153 N.E. 337 (1926); In re Clark, 274 App. Div. 49, 80 N.Y.S.2d 1 (1948); Albert v. Isbrandtsen Co., 7 Misc. 2d 67, 160 N.Y.S.2d 772 (Sup. Ct. 1957); Herring v. Williams, 158 N.C. 1, 73 S.E. 218 (1911); Restatement, Property $\$$ 929, comment $f(1940)$.

${ }^{63}$ Tillett v. Nixon, 180 N.C. 195, 104 S.E. 352 (1920); Parks v. Robinson, 198 N.C. 269, 50 S.E. 649 (1905); Restatement, Property $\$ \S 241,323$ (1940).

os Heiseman v. Lowenstein, 113 Ark. 404, 169 S.W. 224 (1914); Brunton v. Easthampton Sav. Bank, 336 Mass. 345, 145 N.E.2d 696 (1957); Shannonhouse v. Wolfe, 191 N.C. 769, 133 S.E. 93 (1926).

See note 117 infra.
} 
As to the creation of powers of appointment, there are of course hundreds of borderline cases involving the construction of ambiguous language, including the question whether certain words and facts create a power or a trust. ${ }^{66}$ Typical cases involve directions by a testator to his executor or another to distribute property among the testator's "friends" or "relatives" or the like. These directions are variously held to create an absolute gift to the named person, ${ }^{67}$ a void trust for want of a definite beneficiary, ${ }^{68}$ or a valid power of appointment with the named party as the donee. ${ }^{69}$ The wide range of results is due in part to different requirements as to certainty of objects for a power of appointment and the beneficiaries of a trust. As will be seen, a group designation such as the testator's "friends" is valid as a power if any appointee meets the description, but it is invalid as a description of trust beneficiaries unless the court can say of any given person that he was or was not a "friend" of the testator. The Restatement of Property, promulgated in 1938, in discussing a power of appointment with objects described by group designation, stated that "if the group is so described that some persons might reasonably be said to answer the description then the power is valid, but an appointment thereunder may be invalid if it cannot be determined whether the appointee answers the description.'70

When it was originally published in 1935, the Restatement of Trusts required generally that every trust to be valid must have a definite beneficiary ascertainable within the perpetuities period. ${ }^{71}$ Honorary and discretionary trusts have been cited as exceptions to the requirement of a definite beneficiary who can enforce the trust or hold title to the equitable interest. Thus, a bequest "to such of testator's friends and in such amounts as $A$ shall select" creates a valid power, ${ }^{72}$ but a bequest "to $A$ in trust for such of testator's friends as $A$ shall select" is void as a trust for lack of definite bene-

\footnotetext{
oa 3 Powell $\{388$ (1952); Simes \& Smite $\$ 892$.

${ }^{07}$ Harvey v. Griggs, 12 Del. Ch. 232, 111 Atl. 437 (1920); Matter of Ostem, 11 Misc. 2d 179, 177 N.Y.S.2d 990 (Surr. Ct. 1958); Ralston v. Telfair, 17 N.C. 255 (1832); Weiss v. Broadway Nat'l Bank, 204 'Tenn. 563, 322 S.W.2d 427 (1959).

${ }^{08}$ Egleston v. Trust Co., 147 Ga. 313, 93 S.E. 878 (1917); Blunt v. Taylor, 230 Mass. 303, 119 N.E. 954 (1918).

${ }^{\circ}$ Estate of Kuttler, 160 Cal. App. 332, 325 P.2d 624 (1958); In re Lidston's Estate, 32 Wash. 2d 408, 202 P.2d 259 (1949); Restatement, Property $\$ 323$, comment $e$ (1940). 70 Restatement, Property $\$ 323$, comment $h$ (1940).

${ }^{72}$ Restatement, Trusts $\S 112$ (1935). See also Folk v. Hughes, 100 S.C. 220, 84 S.E. 713 (1915).

${ }^{72}$ In re Rowlands' Estate, 73 Ariz. 337, 241 P.2d 781 (1952).
} 
ficiaries. ${ }^{73}$ In passing upon the validity or invalidity of such an arrangement, courts seem unwilling to distinguish between a trust for the benefit of "objects of benevolence" or "public purposes" or "friends," which is clearly void for uncertainty or lack of a definite cestui, and a trust which gives the trustee a power to select from among such persons or purposes. Unfortunately, this represents the majority American view. ${ }^{74}$ In the 1959 revision of the Restatement of Trusts, the necessity for an ascertainable beneficiary is retained, but the selection of a beneficiary by the trustee or another person is permitted under a power, unless the class is "so indefinite that it cannot be ascertained whether any person falls within it." the arrangement may be upheld with a power of appointment if the power is exclusive, and presumably it will be upheld as a trust after the appointment occurs. ${ }^{76}$ However, this attempt to align trust law with property law is "ought" law rather than "is" law, and a gift by will "to my executor in trust to dispose of the same among my friends" remains a trap for the unwary as a matter of trust law unless the term "friends" is sufficiently certain for a court to be able to say of any particular person that he either does or does not qualify as such a "friend." 77

A power may be created subject to a condition precedent, ${ }^{78}$ or it may be in favor of single, multiple, or alternative donees. ${ }^{79}$ In spite of arguments against the delegation of one's power to make a will and violation of statutory formalities for wills and codicils, both inter vivos and testamentary creation of a power of appointment to alter one's will or dispose of his property are upheld on the theory that the donee's exercise of the power is an event on which title shifts from the donor to the appointee. ${ }^{80}$ Although the objects of

${ }^{73}$ Clark v. Campbell, 82 N.H. 281, 133 Atl. 166 (1926).

7s Tilden v. Green, 130 N.Y. 29, 45, 28 N.E. 880 , 881.82 (1891); 4 ScorT $\$ 417$.

${ }^{75}$ Restatenent (Second), Trusts $\$ 122$ (1959).

To Id. $\$ 120$, comment $c$ (1959); id. \$ 122, comment $a$.

7 Estate of Ralston, 1 Cal. 2d. 724, 37 P.2d 76 (1934); Clark v. Campbell, 82 N.H. 281, 133 Atl. 166 (1926); see note 68 supra. See generally Palmer, The Effect of In. definiteness on the Validity of Trusts and Powers of Appointment, 10 U.C.L.A.L. REv. 241 (1963).

${ }^{78}$ Bundy v. United States Trust Co., 257 Mass. 72, 153 N.E. 337 (1926); Massey v. Guaranty Trust Co., 142 Neb. 237, 5 N.W.2d 279 (1942); Smith v. Garey, 22 N.C. 42 (1838).

${ }^{79}$ Wooster v. Union \& New Haven Trust Co., 132 Conn. 309, 43 A.2d 734 (1945); Haslen v. Kean, 4 N.C. 700 (1818).

${ }^{80}$ Columbia Trust Co. v. Christopher, 133 Ky. 335, 117 S.w. 943 (1909); In re McKallip's Estate, 324 Pa. 438, 188 Atl. 343 (1936); In re Watts's Estate, 202 Pa. 85, 51 Atl. 588 (1902). Contra, Zierau v. Zierau, 347 111. 82, 179 N.E. 432 (1931). 
the power acquire no interest under it until an appointment is made, once a power is created, it is irrevocable unless the donor has retained a right to revoke it. ${ }^{81}$

As previously pointed out in the discussion of different types of powers and the purposes to be served by them, the selection of the type of power depends upon the objectives which the property owner wishes to accomplish. If the purpose is to give the donee what amounts for all practical purposes to a fee simple but without its incidents and liabilities, this can be largely achieved by adding a special or general testamentary power to a life estate. Such a donee may be given a power to appoint to anyone in the world except himself, his estate, his creditors or the creditors of his estate and still avoid taxation under the federal estate tax.$^{82}$ The subject property may be made taxable to the donee's estate and the benefit of the marital deduction acquired by coupling the donee's legal or equitable life estate with an inter vivos special power of appointment and a general testamentary power of appointment over the remainder in fee. Of course, one of the principal reasons for utilizing a power of appointment is to achieve flexibility by giving wide discretionary powers of appointment to the donee and thereby extending the donor's ultimate property settlement into the distant future while at the same time saving taxes and other costs.

In summary, the following points regarding the creation of powers of appointment should be carefully dealt with: certainty as to the type of power, whether general or special, presently exercisable or testamentary; explicit provision as to types of interests the donee-may create in exercising the power, including the power to create new powers; certainty that the power authorizes conveyance of the fee when the donee of a power is life tenant of the appointive property; allowance of blanket exercise or the requirement of express reference to the power; provision for exercise by an instrument executed prior to the creation of the power; express designation of the power as exclusive or nonexclusive; appointment of an alternative donee should the donee predecease the donor; inclusion of a default clause covering total or partial failure of exercise and inclusion of a hotchpot clause if the power is special; provision allowing or not allowing release, total or partial, and stating the mechan-

81 Restatement, Property $\$ 337$ (1940).

82 INT. REv. CODE OF 1954, § 2041. 
ics; express provision as to termination of the trust and transfer of the property where a trustee is also donee of the power; specification or other provision concerning the governing state law; and caretul calculation to make certain that the trust does not have a maximum duration in excess of the perpetuities period when a corporate trustee which may exercise the power or acquire such power by succession is involved. ${ }^{83}$

\section{B. Exercise of Powers of Appointment}

For the valid exercise of a power, the concurrence of three factors must be established: that the transaction meets formal legal requirements, that the donee intended to exercise it, and that the exercise is within its scope. ${ }^{84}$ Formal legal requirements for the exercise of a power include the necessary legal capacity of the donee and the proper form of the instrument employed, i.e., a legally valid deed or will. ${ }^{85}$ To whatever extent the exercise of a power of appointment is regarded as a mere event upon which the title to property shifts and not as a conveyance, legal capacity of the donee seems immaterial. ${ }^{88}$ However, since it is legal policy to protect persons who are non sui juris against their assumed indiscretion, the present general requirement is that the donee must have the same legal capacity with respect to the appointive assets as would be required for a conveyance of his own property. ${ }^{87}$ As to release of a power by an infant donee, the common law distinguished between powers appendant and those in gross or merely collateral and refused to sanction release of the first type because it involved the infant's own property. ${ }^{88}$ No such distinctions were observed concerning an adult married woman, and as donee of a power of appointment, she could transfer property which she could not otherwise convey because of the disability of coverture. ${ }^{80}$ Some states provide by statute that the execution of a power by will requires a validly executed will, something an infant is unable to do. ${ }^{90}$

\footnotetext{
${ }^{83}$ STEPHENSON $\$ \S 4.11,4.12$.

84 Restatement, Property $\$ \S 345-47$ (1940).

${ }^{85} I d . \S 346$.

${ }^{86}$ SIMES \& SMITH \& 971.

${ }^{87} 3$ Powell I 399 (1952); Restatement, Property § 345 (1940).

${ }^{88}$ Thompson v. Lyon, 20 Mo. 155 (1854); In re D'Angibau, 15 Ch. D. 228 (1880).

${ }^{89}$ Taylor v. Eastman, 92 N.C. 601 (1885); Browning v. Bluegrass Hardware Co., 153 Va. 20, 149 S.E. 497 (1929); REstatement, PROPERTY \& 345 (1940).

${ }^{\circ}$ Restatement, Property $\$ 346$ (1940); cf. Helvering v. Safe Deposit \& Trust Co., 316 U.S. 56 (1942).
} 
Because it is not presently exercisable, the donee of a testamentary power of appointment can neither exercise it by deed nor make a binding contract to devise the appointive property. ${ }^{91}$

As hereafter noted, the question whether a special power is exclusive or nonexclusive is one of construction, and the present-day preference is for the finding of an exclusive power. By the older strict rule, a special power to appoint "between" or "among" the members of a group was usually construed as a nonexclusive power, thus raising the question of illusory appointment. ${ }^{92}$ As to the requirement of special formalities in the execution of a power, such as a condition that a will executing a testamentary power have more than the legally required number of witnesses, ${ }^{93}$ their observance is generally mandatory, but in some states such unnecessary gestures have been statutorily nullified.94

As to manifestation of an intent to exercise a power by deed or by will, this may occur either by explicit language or by implication. In the absence of an explicit exercise of a power by direct language, it is a question of construction whether there has been a sufficient manifestation by the donee of an intent to exercise the power. ${ }^{95}$ For wills, a form of express exercise is the so-called blanket exercise which disposes of the donee's owned and appointive property together to the same individuals, e.g., "all property which I own or over which I have power of appointment I devise as follows ...." Almost without exception it is the common law rule that the gift in a will of "all my estate" or "the residue of my estate" does not exercise a testamentary power of appointment, because the power is not property..$^{96}$ In a number of states there are statutes, some restricted to general powers, which provide that a general or residuary devise or

${ }^{01}$ Childs v. Gross, 41 Cal. App. 2d 680, 107 P.2d 424 (1940); Northern Trust Co. v. Porter, 368 Ill. 256, 13 N.E.2d 487 (1938); United States Trust Co. v. Montclair Trust Co., 133 N.J. Eq. 579, 33 A.2d 901 (Ch. 1943); Reid v. Boushall, 107 N.C. 345, 12 S.E. 324 (1890); Restatement, Property $\$ 340$ (1940).

${ }^{22}$ See notes $124-27$ infra.

${ }^{\circ 3}$ Hutchinson v. Farmer, 190 Md. 41I, 58 A.2d 638 (1948); National Shawmut Bank v. Joy, 315 Mass. 457, 53 N.E.2d 113 (1944); Restatement, Property $\S 346$ (1940).

of These states include Kentucky, Michigan, Minnesota, New York, North Carolina, North Dakota, Oklahoma, South Dakota, Virginia, West Virginia, and Wisconsin.

${ }^{\circ \sigma}$ Northern Trust Co. v. Cudahy, 339 Ill. App. 603, 91 N.E.2d 607 (1950); RESTATEMent, Property $\$ 342$ (1940).

${ }^{\circ 0}$ Emery v. Emery, 325 Ill. 212, 156 N.E. 364 (1927); In re Proestler's Will, 232 Iowa 640, 5 N.W.2d 922. (1942); Trust Co. v. Nichols, 62 N.J. Super. 495, 163 A.2d 205 (Ch. 1960); Restatement, Property $\$ 343$ (1940). Contra, Slayton v. Fitch Home, Inc., 293 Mass. 574, 200 N.E. 357 (1936) (general power). See 43 B.U.L. REv. 338 (1963). 
bequest of a testator's property includes property over which he has a testamentary power of appointment unless a contrary intent appears by the will. ${ }^{.7}$ These statutes seem justifiable because of the wide use of general testamentary language and the proneness to regard appointive property as one's own, especially where the donee has a life estate with a testamentary power of appointment over the remainder.

According to the common law, a deed or will which did not specifically refer to a power was presumed not to exercise it. ${ }^{08}$ In the language of Justice Story, often repeated in the cases, three classes of cases are held to exercise a power: those where there is a reference to the power, those where there is a reference to the appointive property, and those where the provision in the will or other instrument executed by the donee of the power would be ineffectual unless it exercised the power.99 Specific reference to the power seems the clearest evidence of intent to exercise it. If the donee had a life estate in the property and a power to appoint the fee by deed or will and appointed by deed without mention of the power, it has been held that only his life estate passed because an intent to exercise the power was not clearly manifested;100 however, the better reasoning and result would transfer the fee. ${ }^{101}$ If the donee owns no other interest and conveys the property by description of the appointive assets but without mention of the power, this constitutes an exercise of the power under Story's second or third class. ${ }^{102}$ A power may be exercised by implication when this seems to be required to carry out the purpose expressed by the donee of the power. ${ }^{103}$

or 3 Powell 7397 n.38 (1952); Restatement, Property $\$ 313$ (1940). Sec also Schaeffer v. Haseltine, 228 N.C. 484 , 46 S.E.2d 463 (1948); N.C. GEN. STAT. \$ 31.43 (1950). For what may constitute sufficient evidence to rebut the presumption, see 9 WIGMORE, EvIDENCE $\$ \S$ 2461-72 (3d ed. 1940).

${ }^{98}$ Morgan Guar. Trust Co. v. Funtington, 149 Conn. 331, 179 A.2d 604 (1962); Northern Trust Co. v. House, 3 IIl. App. 2d 10, 120 N.E.2d 234 (1954); Fidelity Union Trust Co. v. Byrne, 76 N.J. Super. 256, 184 A.2d 163 (Ch. 1962); Restatement, Pro1. ERTY $\$ 343(1940)$.

${ }^{\circ}$ Blagge v. Miles, 3 Fed. Cas. 559 (No. 1479) (C.C.D. Mass. 1841); Funk v. Egglestoll, 92 Ill. 515 (1879).

${ }^{100}$ Ferring v. Williams, I58 N.C. 1, 73 S.E. 218 (1911). But see Hood v. N. C. Theatres, Inc., 210 N.C. 346,186 S.E. 345 (1936), seemingly applying the statutory wills presumption to a deed.

${ }^{101}$ Farlow v. Farlow, 83 Md. 118, 34 Atl. 837 (1896).

${ }^{102}$ Lee v. Simpson, 134 U.S. 572 (1890); In re Stork, 233 Iowa 413,9 N.W.2d 273 (1943); Hood v. Francis, 137 N.J. Eq. 200, 44 A.2d 182 (Ch. 1945); Tocci v. Nowfall, 220 N.C. 550, 18 S.E.2d 225 (1942); Lowe v. Ragland, 156 Tex. 504, 297 S.TV.2d 668 (1957).

${ }^{108}$ Board of Home Missions v. Saltmer, 125 N.J. Eq. 33, 4 A.2d 69 (Ch. 1939); 
To summarize regarding exercise of powers of appointment, certain points previously mentioned should be carefully observed. The exercise of a power of appointment requires no particular word formula, and as indicated, it is a question of the intention of the donee, provided the proper formalities have been met. However, the instrument which creates a power of appointment should specify with particularity the manner of its exercise, and in the exercise of the power by the donee, specific reference to the creating instrument and to the power should be made. Also, if there are particular restrictions, such as the giving of written notice to the trustees of the property or the procurement of the required consent of another person, these should be carefully observed and followed. Where a special power is being exercised, the draftsman should be very careful to see that the appointees are objects of the power; and if the creating language of the power leaves open the possibility that the power might be nonexclusive, then a substantial appointment should be made to each object of the power. Express exercise or nonexercise is the only safe rule. If future interests or additional powers are to be created by the exercise of the power, particular care is necessary for protection against violation of the Rule Against Perpetuities, ${ }^{104}$ especially in states having the statutory rule that the residuary clause of a will presumptively exercises any testamentary power held by the testator. ${ }^{105}$ Here the draftsman of the will must be careful to distinguish between owned and appointive property.

In determining whether a power should be exercised, general and special powers differ when there is no default clause. If the power is special, failure to exercise the power may result in the court's making a per capita distribution of the property to the objects of the power either by treating it as an imperative power or power in trust or by implying a gift in default of appointment to them. ${ }^{106}$ If a general and unexercised power is involved, the property usually

Woody v. Pickelsimer, 248 N.C. 599, 104 S.E.2d 273 (1958); Buncombe County v. Wood, 216 N.C. 224, 4 S.E.2d 505 (1939); Johnston v. Knight, 117 N.C. 122, 23 S.E. 92 (1895).

${ }^{104}$ See note 159 infra.

${ }^{100}$ See note 97 supra.

${ }^{100}$ First Portland Nat'l Bank v. Rodrique, 157 Me. 277, 172 A.2d 107 (1961); Massachusetts Institute of Technology v. Loring, 327 Mass. 553, 99 N.E.2d 854 (1951); Henderson v. Western Carolina Power Co., 200 N.C. 443, 157 S.E. 425 (1931); Bridgewater v. Turner, 161 Tenn. 111, 29 S.W.2d 659 (1930); Restatement, Property $\S$ 367 (2)- (4) (1940). 
reverts to the donor or his estate..$^{107}$ However, if an attempted exercise is ineffective, it may be awarded to the donee or his estate under the doctrine of capture, whether or not there is a default clause. ${ }^{108}$ If there is a default clause, as to the power's exercise, the donee must consider, in addition to such factors as taxes and subjection to claims of the donee's creditors or his surviving spouse's rights, whether the form of the default clause is sufficiently explicit to avoid litigation over the shares in which the takers in default will receive the property, and whether they are capable, both legally and practically, of being its owners as the clause provides. ${ }^{109}$

VI

\section{Scope of Powers of Appointment-General and Special}

As to the scope of the power granted, there are several different aspects in which it may be greater or less. First, the donor may give the donee carte blanche in the choice of appointees, or he may impose rigid restrictions or negligible ones. The principal classifications in this respect are the general power and the special power, which have been discussed earlier. If property is transferred to $A$ for life, remainder as he shall appoint, this creates a general power, and $A$ can appoint the remainder to anybody in the world, including himself or his estate. ${ }^{110}$ Between general and special powers then, the determining factor is whether or not the donee may appoint to himself or his estate. Under a special power, the donee is restricted to appointing to a specifically named group of persons and cannot appoint to himself either directly or indirectly.111

Second, as to a special power, the donor can limit not only the objects but also the type of interests the donee may create in the appointees. ${ }^{112}$ Under a general power the donee has absolute right

\footnotetext{
${ }^{107}$ Oglesby v. Springfield Marine Bank, 385 Ill. 414, 52 N.E.2d 1000 (1914); Bond v. Moore, 90 N.C. 235 (1884); Harris v. Battle, 21 N.C. 213 (1835); Polen v. Baird, 125 W.Va. 682, 25 S.E.2d 767 (1943); Restatement, Property $\$ 367$ (1) (1940).

${ }^{108}$ Fiduciary Trust v. Mishou, 321 Mass. 615, 75 N.E.2d 3 (1947); Talhott v. Riggs, 287 Mass. 144, I9I N.E. 360 (1934); 3 Poweli If 402 (1952); Restatement, Property $\$ 365(1940)$.

${ }^{100}$ See Stephenson $\$ \S 4.11,4.12$.

${ }^{110}$ Frank v. Frank, 305 Ill. 181, 137 N.E. I51 (1922); Mabry v. Brown, 162 N.C. 178, 78 S.E. 78 (1913); Stroud v. Morrow, 52 N.C. 357 (1860); RESTATEMENT, Property $§ 320$ (1940).

${ }^{111}$ Horne v. Title Ins. \& Trust Co., 79 F. Supp. 91 (S.D. Cal. 1948); Pitman v. Pitman, 314 Mass. 465, 50 N.E.2d 69 (1943); Holt v. Hogan, 58 N.C. 78 (1859). But see First Portland Nat'l Bank v. Rodrique, 157 Me. 277, 172 A.2d 107 (1961). 112 Culbreth v. Caison, 220 N.C. 7I7, I8 S.E.2d I36 (1942).
} 
as to both types of interest creatable and possible appointees. It is well settled that the donee of a general power may appoint the subject property with the same freedom that he might convey his own property because he can first appoint it to himself and then convey it as owner. ${ }^{113}$ He may appoint the property outright or in trust, ${ }^{114}$ create life estates and future interests, ${ }^{115}$ create new powers and impose conditions and limitations upon such appointment, ${ }^{116}$ or mortgage the property. ${ }^{117}$ The donee of a special power may, with certain exceptions, appoint the property in the same way. As to the scope of a power in terms of interests creatable thereunder, if the creating instrument is not specific, litigation to construe the instrument and find the donor's intent is likely. This is particularly true where a power is special as distinguished from general. However, for both the creation and exercise of powers, the only safe course is explicit draftsmanship.

\section{VII}

\section{Special Scope Problems of Speclal Powers of Appointment}

There are a number of other aspects of the scope of a special power: e.g., (1) its objects, (2) the interests creatable under it, (3) whether it is exclusive or nonexclusive, (4) whether it is mandatory or discretionary, (5) whether it is releasable in whole or in part, and (6) whether new powers may be created. These may be illustrated by reference to the following hypothetical disposition: $T$ devises property to his son $A$ for life, with power to appoint the remainder among $A$ 's children as he shall see fit, and to the extent that it is not effectively appointed, the remainder is to pass to $A$ 's children in fee simple. This is a common type of provision which on its face seems sufficiently certain, but it is in fact replete with legal problems.

(1) As to the objects of a special power, since the designation is

${ }^{118}$ Regents of the Univ. Sys. v. Trust Co., 186 Ga. 498, 198 S.E. 345 (1938); Hicks v. Ward, 107 N.C. 303, 12 S.E. 318 (1890); Restatement, Property $\S 356$, comment $b$ (1940).

116 Wilmington Trust Co. v. Sloane, 30 Del. Ch. 103, 54 A.2d 544 (1947); Regents of the Univ. Sys. v. Trust Co., supra note 113; Matter of Finucane, 193 Misc. 439, 82 N.Y.S.2d 471 (Surr. Ct. 1948).

${ }_{118}$ Equitable Trust Co. v. James, 29 Del. Ch. 166, 47 A.2d 303 (1946); Lamkin v. Safe Deposit \& Trust Co., 192 Md. 472, 64 A.2d 704 (1949); Matter of Finucane, supra note 114 .

${ }^{110}$ Marx v. Rice, 1 N.J. 574, 65 A.2d 48 (I949); Restatemenr, Property $\$$ 356, comment $d$ (1940).

117 Wachovia Bank \& Trust Co. v. Heymann, 220 N.C. 526, 17 S.E.2d 665 (1941); Ferrell v. Metropolitan Life Ins. Co., 211 N.C. 423, 190 S.E. 746 (I937). 
by a group or class description, its creation involves the construction or definitional problems of class gifts such as the inclusionary and exclusionary force of terms like heirs, issue, and children.118 Any appointment to or for a non-object of the power is void.110 Since the above hypothetical power confines appointment to $A$ 's children, grandchildren would ordinarily be excluded.129 Also, in case a child of $A$ predeceased him, leaving a widow or a widow and issue, provision could not be made for them under this power. ${ }^{121}$ Thus, the inclusion of a definitional clause in the creating instrument clarifying such key dispositive words as "children," "issue," and "heirs" would seem to be in order. When the donee exercises the power, he encounters not only the definitional aspects of class gifts if he appoints to a class, but also such additional problems as the rules concerning class closing, lapse, survivorship, shares and such, many of which can be eliminated by careful drafting. ${ }^{122}$

(2) As to the interests creatable by the donee, the language of the hypothetical power gives no clue as to whether the donee may appoint in trust or create limited interests with remainders. The general rule is that there is no prohibition on this type of exercise, and in the absence of a contrary direction, the donee of a special power is privileged to do any of the things allowed for a general power, provided it does not benefit a non-object of the power. ${ }^{123}$ Certainly in the average case, the donee of such a power should be permitted to create not only limited estates and interests but also appropriate trusts required under the circumstances. As to both the objects of the power and types of interests creatable by the exercise

118 Casner, Class Gifts-Definitional Aspects, 41 Colum. L. REv. 1 (1941); Long, Class Gifts in North Carolina, 22 N.C.L. Rev. 297 (1944); Schuyler, Class Gifts in Illinois, 34 ILL. L. REv. 893 (1940).

${ }_{110}$ Matter of Kennedy, 279 N.Y. 255, 18 N.E.2d 146 (1938); Hodges v. Stegall, 169 Tenn. 202, 83 S.W.2d 901 (1935).

${ }_{120}$ Equitable Trust Co. v. Foulke, 28 Del. Ch. 238, 40 A.2d 713 (1945); Matter of Kennedy, supra note 119; Carson v. Carson, 62 N.C. 50 (1866).

${ }^{121}$ Equitable Trust Co. v. Foulke, supra note 120; Rankin v. Hoyle, 41 N.C. 123 (1848); In re Lewis' Estate, 349 Pa. 571, 37 A.2d 482 (1944). But see Carson v. Carson, supra note 120 .

122 Bolich, Some Common Problems Incident to Drafting Dispositive Provisions of Donative Instruments, 35 N.C.L. REv. 17, 23-30 (1956); Phillips, Some Suggestions to Will Draftsmen: Complex Dispositive Provisions in General, Class Gift Provisions in Particular, 40 N.C.L. REv. 23 (1961).

${ }^{123}$ Union \& New Haven Trust Co. v. Taylor, 133 Conn. 221, 50 A.2d 168 (1946); Welch v. Morse, 323 Mass. 233, 81 N.E.2d 361 (1948); Matter of Hopkins, 72 N.Y.S.21 702 (Surr. Ct. 1947); In re McNeile's Estate, 217 Pa. 179, 66 Atl. 328 (1907); Rustatr. MIENT, Property \$\$ 356-57 (1940). 
of the power, great care must be exercised in the creation of a special power in order to provide for various possible changes of circumstances which may arise. Draftsmen must have an eye for both precision of meaning and latitude of action. Assuredly, in our example $T$ would have desired his daughter-in-law or his grandchild to benefit or a spendthrift to be protected against his indiscretion by an appropriate trust. It is the lawyer's duty to peer into the future with his client in this respect and guide his thinking. Unless there is an attempt to foresee the contingencies, a special power of this kind may be entirely too limited to provide for the unknown future.

(3) Whether the power is exclusive or nonexclusive is not made clear by the creating language. May the donee discriminate between his children by appointing unequally among them or by entirely eliminating one or more of them? It is generally said that a special power is presumed to be exclusive, ${ }^{124}$ but courts naturally turn such decisions on the words used, ${ }^{125}$ and one cannot afford to invite construction litigation when drafting can be explicit on this point. However, it should be pointed out that the minimum cannot be too small because application of the illusory appointment rule requires that each appointee receive a substantial sum. ${ }^{126}$ Although some states repudiate this doctrine, ${ }^{127}$ in those where the rule applies, the minimum should be designated when the power is drafted, possibly expressed as a percentage of the available fund.

(4) Whether exercise of the power is mandatory or discretionary raises the question whether it is a mere special power or the type of power known as a power in trust. The Restatement classifies powers merely as general or special, and because a power is discretionary, it does not accept the common law power in trust concept which is an imperative power.128 As to it, the Restatement of Trusts says the donee is a trustee of the power of appointment, the subject of the

${ }^{124}$ Harlow v. Citizens Nat'l Bank, 251 S.W.2d 284 (Ky. 1952); Moore v. Emery, 137 Me. 259, 18 A.2d 781 (1941); National State Bank v. Morrison, 7 N.J. Super. 333, 70 A.2d 888 (Ch. 1949), modified, 9 N.J. Super. 552, 75 A.2d 916 (Ch. 1950); Matter of Barbot, 144 N.X.S.2d 809 (Surr. Ct. 1955); Restatement, Property $§ 360$ (1940).

2203 POWELl $\$ 398 \mathrm{nn} .90 \& 91$ (1952).

120 Hatchett v. Hatchett, 103 Ala. 556, 16 So. 550 (1893); Matter of Sloan's Estate, 7 Cal. App. 2d 319, 46 P.2d 1007 (1935); Restatement, Property $\$ 361$ (1940).

${ }^{127}$ Hawthorn v, Ulrich, 207 Ill, 430, 69 N.E. 885 (1904); Hodges v. Stegall, 169 Tenn 202, 83 S.W.2d 901 (1935).

${ }^{228}$ Restatement, Property $\$ \S 320,323$ (1940). 
trust, and that there must be a definite cestui for its validity, ${ }^{120}$ subject to a 1959 amendment sanctioning his selection by the trustee or another under a power. ${ }^{130}$ As previously pointed out, the power in trust concept is recognized in some states; and although equity will not normally enforce or aid the nonexecution of a power of appointment because it involves a personal discretion, if it finds the power to be in the nature of a trust, it may divide the appointive property equally among the objects of an unexercised power. ${ }^{131}$

(5) As to release of a power by the donee, general powers are freely releasable, ${ }^{132}$ and the same is now usually true for special powers, except powers in trust. ${ }^{133}$ However, the common law decisions are not uniform. Allowing the donee to release his power aids alienation and may enhance the value of the property and estate in question under certain circumstances; but in the case of a testamentary power, release frustrates the donor's intent that the donee's discretion should not be foreclosed until his death, ${ }^{134}$ and in principle it is contrary to the rules forbidding inter vivos exercise of the power or a contract to exercise it. ${ }^{135}$ If a power is releasable, a release may be effected at common law by delivery of an instrument under seal or upon consideration so stating to a person who would be adversely affected by an appointment, ${ }^{136}$ by a contract witl such person, ${ }^{137}$ or by the donee's joining the takers in default in a conveyance of the property subject to the power. ${ }^{138}$ The Federal Revenue Act of 1942 provided that a special power conforming to statutory specifications would cause the appointive assets not to be in-

\footnotetext{
${ }^{229}$ Restatement (Second), Trusts $\$ 27$ (1959).

130 See note 75 supra.

131 See note 106 supra.

${ }^{232}$ Weil v. United States, 148 Ct. Cl. 681, 180 F. Supp. 407, cert. denied, 364 U.S. 822 (1960); McFall v. Kirkpatrick, 236 Ill. 281, 86 N.E. 139 (1908); RESTATEMENT, ProperTY $\S 334$ (1940).

${ }^{233}$ Chickering v. Commissioner, 118 F.2d 254 (lst Cir.), cert. denied, 314 U.S. 636 (1941); Hill v. Sangamon Loan \& Trust Co., 302 Ill. 33, 134 N.E. 112 (1922); RrstatEMENT, Property $\S 335$ (Supp. 1948); Nossaman, Release of Powers of Appointment, 56 HaRv. L. REv. 757 (1943).

134 O'Hara v. O'Hara, 185 Md. 321, 44 A.2d 813 (1945).

135 See note 91 supra.

${ }^{138}$ District of Columbia v. Lloyd, 160 F.2d 581 (D.C. Cir. 1947); Merrill v. Lynch, 173 Misc. 39, 13 N.Y.S.2d 514 (Sup. Ct. 1939); Restatement, Property $\$ 336$ (1) (1940). ${ }^{137}$ Hill v. Sangamon Loan \& Trust Co., 302 Ill. 33, 134 N.E. 112 (1922); REsTATEMENT, Property §336(3) (1940). But see Browne v. Hendley, 216 Ga. 411, 116 S.E.2d 537 (1960).

${ }^{138}$ Voncannon v. Hudson Belk Co., 236 N.C. 709, 73 S.E.2d 875 (1953); RestateMENT, Property $\$ 336(2)(1940)$.
} 
cluded in the donee's estate for federal estate tax purposes and allowed donees to release their present powers without gift tax liability. ${ }^{130}$ This produced a rash of state statutes permitting release of powers of appointment, ${ }^{140}$ which caused the Restatement of Property to change its position regarding the release of special powers by permitting their release, whether inter vivos or testamentary, unless the donor had expressed a contrary intent. ${ }^{141}$ The terms of these statutes vary, and some may be of limited value because they deal merely with the formalities of release of a power which is releasable at common law.142 Of course, any donee may refuse to accept a power by renunciation or disclaimer, but this is a different matter from the right to release a power which has been accepted. ${ }^{143}$ It would seem desirable when drafting a power to provide specifically whether release is permissible in whole or in part and to specify the mechanics of a release. The desirability of specifically sanctioning the release of special powers may be questioned in view of their nature and the donor's apparent desire to benefit the objects.

(6) As to the donee's creation of new powers, when allowed, although analogous to a delegation of his discretion, creation is generally upheld provided a non-object is not thereby benefited.144 Powers, of course, are personal and cannot be delegated ${ }^{145}$ or assigned, ${ }^{146}$ and, if unexercised, die with the donee. ${ }^{147}$ As stated earlier, the discretion to create a new power by an exercise of one's special power may be very desirable, especially if the appointment is in trust. Every well-drafted power should always include an explicit provision with regard to creation of new powers by its exercise; otherwise, a troublesome problem of construction is always present.

\footnotetext{
${ }_{100}$ Federal Revenue Act of 1942, $\S \S 403$ (d) (3), 452 (c), 56 Stat. 944, 952, amending INT. REv. CODE of 1939, $\S \S 811$ (f), 812 (d) 826 (d), 861 (a) (3), 1000 (c) (now INT. REv. CODE OF 1954, §§ 2041, 2055, 2106 (2) (B), 2207, 2514 (a)).

1 10 3 Powell of 394 n.93 (1952) lists 30 states having such statutes.

111 Restatement, Property \$\$ 504-09 (Supp. 1948).

142 3 Powell ๆ 394 n.93 (1952); N.C. GEN. STAT. $\$ \S 39-33$, $39-36$ (1950) seem a prime example.

145 SIMEs \& SMith \& 1061.

14 National State Bank v. Morricon, 7 N.J. Super. 333, 70 A.2d 888 (Ch. 1949), modified, 9 N.J. Super. 552, 75 A.2d 916 (Ch. 1950); In re Hopkins' Estate, 72 N.Y.S.2d 702 (Surr. Ct. 1947); ResTateMeNT, PROPERTY $\$ 359$ (1940).

${ }_{165}$ Thayer v. Rivers, 179 Mass. 280, 60 N.E. 796 (1901).

${ }_{140}$ Merchants Nat'l Bank v. Morrissey, 329 Mass. 601, 109 N.E.2d 821 (1953).

${ }^{147}$ Henwood Trust, 11 Fid. Rep. 199 (Pa. Orphans' Ct. 1961). But see Haslen v. Kean, 4 N.C. 700 (1818).
} 


\section{VIII}

\section{Some Common Legal Problems Regarding Greation and} EXERcise of Powers of AppoIntMENT

\section{A. Exercise Before the Power is Created}

As to date of creation and date of exercise, a power cannot be exercised by the donee's deed or will which becomes operative before the power is created, but a power in existence at the donee's death, although created after the execution of his will, may be exercised by it. ${ }^{148}$ Though a power cannot in logic be exercised before its creation, courts sometimes avoid the consequences of this fact and uphold such appointments in hard cases by various devices, including the doctrine of incorporation by reference and acts having independent legal significance. ${ }^{149}$ It is usual to provide expressly for such appointments.

\section{B. Gift in Default of Appointment}

Whether a power is general or special, it seems mandatory that a gift in default of appointment be included. If the gift in default is not carefully drafted or is not included, litigation is almost certain to occur if the power is not exercised by the donee. As previously stated, when there is a general power and no gift in default and the power is not exercised, the property reverts to the donor or his estate; but if an attempted exercise is ineffective, the doctrine of capture may result in the property being awarded to the donee or his estate, even though there is a default clause. ${ }^{150}$ If a special power is unexercised, the court may imply an appointment to the objects of the power and make a per capita distribution of the property. ${ }^{151}$ Not only should there be a well-drafted default clause in terms of takers and nonexercise, but it should also provide for defective or partial exercise by the making of a gift over "to the extent that the power is not effectively exercised," instead of the conventional formula of yesterday, "in default of and until appointment." Possibly a hotchpot provision should also be included.

\footnotetext{
${ }^{148}$ Curley v. Lynch, 206 Mass. 289, 92 N.E. 429 (1910); Matter of Davis, 186 Misc. 397, 59 N.Y.S.2d 607 (Sup. Ct. 1946); Matter of Mayo, 76 Misc. 416, 136 N.Y.S. 1066 (1912); Restatement, Property \$\$ 344, 348 (1940).

${ }^{169}$ Bemis v. Fletcher, 251 Mass. 178, 146 N.E. 277 (1925); Matter of Fowles, 222 N.Y. 222, 118 N.E. 611 (1918); 26 HARv. L. REv. 91 (1912); see Restatement, Property $\S 348$, comments $e, f(1940)$.

${ }^{250}$ Sce notes 107,108 supra.

${ }^{161}$ See note 106 supra.
} 


\section{Lapse and Pretermission}

If a legatee or devisee predeceases the testator, the gift lapses except to the extent that the will itself or an anti-lapse statute provides a substitute taker, and such statutes now exist in nearly every state. ${ }^{162}$ In a typical power of appointment case, $T$ by will creates a general testamentary power of appointment. If the donee predeceases the donor, it is usually held that the power lapses or never comes into being. ${ }^{153}$ If the donee survives and makes an appointment by his will and the appointee predeceases him, courts generally disregard the relation back theory and apply an otherwise applicable anti-lapse statute to the appointed property just as though the donee were the testator-owner. ${ }^{154}$ As to the application of an anti-lapse statute to a special testamentary power, it can in no event apply unless the statutory substitute taker is an object of the power. ${ }^{155}$ Even where the substitute taker is an object and also bears the required relationship to the donee, ${ }^{156}$ since the donee of a special power is in no sense regarded as the owner of the property, an antilapse statute should not apply on any such theory, regardless of intent.

By virtue of statute in nearly every state, if a child is omitted from his parent's will, under certain conditions he is entitled to his intestate share of the estate. ${ }^{157}$ On reasoning similar to the lapse cases, some courts permit such a pretermitted child to share in property appointed by the donee-parent as if he owned it. ${ }^{158}$ Since these statutes are designed to effectuate a testator's presumed intent, it would seem that the donee's intent is the intent at issue where the appointment is made by will and the appointee predeceases the donee-testator or pretermission of a child occurs. Thus, both as to

\footnotetext{
1623 Powell 9367 (1952); Restatement, Property \$ 298, comment $c$ (1940).

${ }^{153}$ In re McCurdy's Estate, 197 Cal. 276, 240 Pac. 498 (1925); Curley v. Lynch, 206 Mass. 289, 92 N.E. 429 (1910).

${ }^{156}$ Newton v. Bullard, 181 Ga. 448,182 S.E. 614 (1935); Thompson v. Pew, 214 Mass. 520, 102 N.E. 122 (1913); In re Goodman, 155 N.Y.S.2d 424 (Sup. Ct. 1956); RESTATEMENT, PRORERTY $\$ 350$ (1940); 4 DURE B.A.J. 119 (1936).

${ }_{265}$ Daniel v. Brown, 156 Va. 563 , 159 S.E. 209 (1931).

${ }_{150} 3$ Powell I 399 (1952); SiMEs \& SMITH \& 984. See also Bolich, Acts Barring Property Rights, 40 N.C.L. REv. 175, 212-13 (1962) for a discussion of N.C. GEN. STAT. \$31A-10(2) (Supp. 1961), a statutory provision where an appointee willfully and unlawfully kills the donee.

${ }_{157}$ Atrinson, Wress $\$ 36$ (2d ed. 1953).

${ }_{108}$ Commonwealth v. Fidelity \& Columbia Trust Co., 285 Ky. 1, 146 S.W.2d 3 (1940); In re Schoch's Estate, $271 \mathrm{~Pa}$. 158, 114 Atl. 502 (1921). Contra, Rhode Island Hosp. Trust Co. v. Anthony, 49 R.I. 339, 142 Atl. 531 (1928).
} 
testamentary creation and exercise of powers, it is in order to provide for the possibility of the donee predeceasing the donor or the appointee, and the pretermission of a child.

\section{Application of the Rule Against Perpetuities}

In both the creation and exercise of powers of appointment, the Rule Against Perpetuities constitutes an ever present danger. This is particularly true when substantial wealth is involved and every effort is being made to minimize taxes through the utilization of trusts, powers of appointment, and future interests designed to shield the property involved to the full extent allowed by the common law or some other rule against perpetuities. Thus, the second or even the third estate tax on the property may be avoided by the use of life estates and remainders for the maximum period the Rule Against Perpetuities allows ultimate disposition to be postponed.

In the creation of powers of appointment, the draftsman should hoist the red flag of danger if the donee is a natural person who is not in esse when the power is created, or even though he is in esse, whenever the power may be exercised by a successor-donee who is not in esse at the date of creation of the original power. Likewise, where a corporate donee may exercise the power in favor of persons not in esse at its creation, caution is counselled. For a general power presently exercisable to be valid, it must become exercisable, if at all, within the perpetuities period which, at common law, is lives in being at the creation of the power and twenty-one years plus any actual gestation periods involved. ${ }^{159}$ Therefore, such a power given to the survivor of a class of unborn persons is invalid because the donee may not be ascertained within the allowable period. Thus a conveyance to $A$ for life, remainder to his first son for life with a general power to appoint by deed when he attains age twenty-two is void if $A$ has no son living when the conveyance is made. ${ }^{100}$ That an actual exercise of the power may occur beyond the period is imma. terial because the objective of the Rule Against Perpetuities is to prevent the undue tying up of property, and a general power presently exercisable is regarded as the equivalent of absolute ownership because the donee can at any time make himself the complete owner.

\footnotetext{
${ }^{150}$ Gray, The Rule Against Perpetuities $\$ 473$ (4th ed. 1942); Restatement, PRoperTy $\$ 374(1940)$.

${ }^{100}$ Appeal of Mifflin, $121 \mathrm{~Pa} .205,15$ Atl. 525 (1888); In re Hargreaves, $43 \mathrm{Ch}$. D. 401 (1890); Restatement, Property § 390 (1) (1940).
} 
Thus, it is only necessary that it be certain at the moment of its creation that such a power will either be freed of any condition precedent to its exercise or that it will fail within the period of the Rule. ${ }^{161}$ As to creation of all special powers and of general testamentary powers, they are treated alike and are valid only if it is not possible for the power to be exercised beyond the period of the Rule Against Perpetuities. Thus, a conveyance to $A$ for life, remainder to his first son for life, remainder as he shall appoint by will is void if $A$ has no son living when the conveyance is made. ${ }^{162}$

While it seems that with few exceptions an indestructable private trust may not have a perpetual duration, ${ }^{163}$ it is settled that since the Rule Against Perpetuities is concerned only with vesting, the duration of a private trust is not subject to the Rule Against Perpetuities if the interests are vested, ${ }^{164}$ and the administrative powers of the trustee of such a trust are also valid. ${ }^{165}$ However, if a discretionary or "sprinkling" trust is so created that it may last beyond the perpetuities period, with the corporate trustee having power to sprinkle income among the beneficiaries, to pay out or accumulate income, or to distribute corpus to or among such beneficiaries, such a power is void if it might be exercised at a time beyond the perpetuities period. ${ }^{166}$ Thus, if a testamentary trust is created to sprinkle income and to pay out or accumulate income or to distribute corpus at the trustee's discretion among the testator's children and grandchildren for their lives and at the death of the survivor to transfer the corpus to a named charity, all the interests are vested. However, the provision for the grandchildren who were not living at the testator's death is void because the trustee's special power of appointment may be exercised beyond the period of the Rule. In essence the discre-

101 Bray v. Bree, 2 Clark \& F. 459, 6 Eng. Rep. 1225 (H.L. 1834).

102 Northern Trust Co. v. Porter, 368 IIl. 256, 13 N.E.2d 487 (1938); Hopkinson v. Swaim, 284 Ill. 11, 119 N.E. 985 (1918); Camden Safe Deposit \& Trust Co. v. Scott, 121 N.J. Eq. 366, 189 Atl. 653 (Ct. Err. \& App. 1937); Restatement, Property $§ 390$ (2) (1940). Contra, Miller v. Douglass, 192 Wis. 486, 213 N.W. 320 (1927).

1035 Powell I 772 (1962); Restatement, PRoperty $\$ \S 378,381$ (1940); Morray, The Rule Against Prolonged Indestructibility of Private Trusts, 44 IL.. L. REv. 467 (1949). 106 Trippe v. National Newark \& Essex Banking Co., 98 N.J. Eq. 462, 131 Atl. 162 (Ch. 1925); McQueen v. Branch Banking \& Trust Co., 234 N.C. 737, 68 S.E.2d 831 (1952). ${ }^{106}$ Melvin v. Hoffman, 290 Mo. 464, 235 S.W. 107 (1921); Restatement, Property $\S 382(1940)$.

${ }^{100}$ Davenport v. Davenport Foundation, 36 Cal. 2d 67, 222 P.2d 11 (1950); Bundy v. United States Trust Co., 257 Mass. 72, 153 N.E. 337 (1926); Re Hubbard's Will Trusts [1962] 2 ALI.E.R. 917 (Ch.); 1 Scotr $\$ 62.10$ (4); REstatemENT, Property $\$ 390$, comment $g$ (1940). 
tionary trust is a special power of appointment, although it is not always so recognized. ${ }^{167}$ Because of its frequent use in discretionary and other trusts, another matter to be borne in mind for trusts which may last longer than the perpetuities period is the rule against accumulations which makes a power to accumulate income liable to invalidity on the ground that such accumulation is illegal. At common law the allowable accumulation period is the same as the Rule Against Perpetuities, ${ }^{168}$ and this is the rule in most American states, although the period has been shortened by statute in some jurisdictions. ${ }^{169}$ As to any testamentary discretionary trust or accumulation trust which might last beyond the perpetuities period, in order to prevent invalidity on the ground of infraction of the rules stated above, it should be specifically provided that twentyone years after the death of the last survivor of named or identified persons living at the testator's death, accumulation should terminate and income should be paid currently, and sprinkling of income or principal among beneficiaries should likewise cease at that time. In view of such considerations, it would seem wise to limit the duration of a private trust to the applicable perpetuities period, both because the maximum common law period would ordinarily provide a century of duration and because such a durational rule seems to be crystallizing. ${ }^{170}$

As to the exercise of powers of appointment, different rules apply to general powers presently exercisable and to all special powers and general testamentary powers. Since a general power presently exercisable is the practical equivalent of ownership in terms of freedom of alienation, the time for validity of appointments under such a power for purposes of the Rule Against Perpetuities is calculated from the date of exercise of the power. ${ }^{171}$ On the other hand, if the power is a special power and is exercisable by deed or will or if it is a general power exercisable only by will, the validity of such appointments for purposes of the Rule Against Perpetuities is measured from the date of the creation of the power because the donee

${ }^{107}$ See Parker v. Parker, 252 N.C. 399, 113 S.E.2d 899 (1960).

${ }^{108}$ Burdick v. Burdick, 123 F.2d 924 (D.C. Cir. 1941); Equitable Trust Co. v. Ward, 29 Del. Ch. 206, 48 A.2d 519 (1946); Rhode Island Hosp. Trust Co. v. Otis, 77 R.I. 296, 75 A.2d 210 (1950); Restatement, Property $\$ 441$ (1940).

1093 Powell If 831 (1952).

170 See Morray, supra note 163. $(\mathrm{Ig} 40)$.

${ }^{171}$ Appeal of Mifflin, 121 Pa. 205, 15 Atl. 525 (1888); Restatement, Property $\$ 391$ 
may not at will make himself the complete owner. ${ }^{172}$ For both a general testamentary power and a special power, a different rule is applicable under the doctrine of the "second look." Under this doctrine, an appointment is invalid under the Rule Against Perpetuities only to the extent that its exercise or limitation, construed in the light of the circumstances existent when the power is exercised but measured for the purpose of applying the Rule from the time when the power was created, violates the Rule because such appointed interests are not certain to vest within that time. For example, if property is bequeathed in trust to pay the income to the testator's son $A$ for life, remainder as he shall appoint by will to his children, and $A$ by will appoints the income to his children for life, remainder at the death of the survivor of his children to his lineal descendants then living, such an appointment is valid if $A$ 's only children were in esse at the testator's death. ${ }^{173}$ Thus, the facts are judged not on the basis of what might have happened in the future as of the date of the donor-testator's death but on the basis of what has happened between the date of the testator's death and the date of the appointment by the donee, and then on the basis of what might happen after the date of the appointment. This enables the donee of a general testamentary power or of a special power of appointment to appoint interests which the donor himself, the testator in this case, could not have validly created.

Since an appointment under a testamentary power or a special power must, subject to the doctrine of the "second look," be read back into the creating instrument, the risk of making invalid appointments by oversight is acute in the case of the blending of the donee's own property with property over which he has such a power of appointment. Thus, if the donee creates a residuary trust "of all the residue of my estate, including property over which I shall hold any power of appointment," such a trust is often valid as to his own property but invalid as to the appointive property. ${ }^{174}$ While it is not the common law rule, in many states a residuary clause is by

${ }^{173}$ Northern Trust Co. v. Porter, 368 Ill. 256, 13 N.E.2d 487 (1938); American Trust Co. v. Williamson, 228 N.C. 458, 46 S.E.2d 104 (1948); Restatement, Property $§ 392$ (1940).

${ }_{173}$ Sears v. Coolidge, 329 Mass. 340, 108 N.E.2d 563 (1952); In re Warren's Estate, 320 Pa. 112, 182 Atl. 396 (1936); Restatement, Property $\$ 392$ (1940); Newhall, Doctrine of the "Second Look," 92 TRUSTs \& Estates 13 (1953).

${ }^{174}$ Amerige v. Attorney Gen., 324 Mass. 648, 88 N.E.2d 126 (1949). 
statute deemed to exercise testamentary powers of appointment. ${ }^{175}$ Therefore, by way of protection against inadvertant exercise, the creator of a power of appointment should require that it be specifically referred to in order to be exercised, or the draftsman of the donee's will should either expressly negate the exercise of the particular power or include a clause which excludes the exercise of any power of appointment which is not specifically referred to in the will.

\section{E. Conflict of Laws}

The increasingly peripatetic habits of Americans and the multistate contacts of property ownership underscore the necessity for the estate planner and draftsman to be alert to certain conflict of laws problems lest his client's estate plan and its disposition be frustrated by the application of arbitrary conflicts rules which might have been averted by proper foresight and drafting. While the hazard of attempting to suggest reliable guidelines in this area of law is recognized, at least some general observations seem to be called for in a discussion of this kind. In the solution of typical conflicts problems involving trusts, there are three sets of variables in the applicable rules, depending upon (1) whether the res consists of movables or immovables, (2) whether the trust is inter vivos or testamentary, and (3) the type of problem at issue, i.e., validity, such as capacity of parties or compliance with local property law; construction, such as the meaning of terms like "children" or the closing of a class; and administration, such as the trustee's powers or allocation of dividends. ${ }^{176}$

In their decisions the courts are making an effort to keep the law measurably abreast of social conditions. This effort is manifested by a growing tendency in judicial choice of law situations involving trusts and estates for courts to modify traditional conflicts concepts so that undue disruption of an expressed dispositive plan may be avoided by the selection of the most favorable law. ${ }^{177}$ As to inter vivos trusts of movables, and possibly as to such testamentary trusts, the settlor or testator is permitted to specify in the deed or will the state law which shall govern the transaction, provided it does not

\footnotetext{
${ }^{275}$ Schaeffer v. Haseltine, 228 N.C. 484,46 S.E.2d 463 (1948); N.C. GEN. STAT. $§ \S 31-$ 43 (1950); Restatement, Property § 343 (1940). See notes 96, 97 supra.

1704 POWELL I 534 (1954).

${ }^{277}$ See generally Ester \& Scoles, Estate Planning and Conflict of Laws, 24 O1110 ST L.J. 270 (1963); Scoles \& Rheinstein, Conflict Avoidance in Succession Planning. "II Law \& Contemp. Prob. 499 (1956).
} 
violate settled public policy of the situs state and has some reasonable connection with the transaction. ${ }^{178}$ If the instrument contains no such express designation of a governing law and the settlor's intent is not otherwise made clear, the state law applied is generally that of the jurisdiction having closest contact or connection with the trust. Such contacts include the place where the trust is to be administered, the situs of the trust res, the trustee's place of business, the domicile of the parties, and the place of execution of the trust instrument. ${ }^{179}$ Subject to the doctrine of equitable conversion, as to inter vivos or testamentary trusts of immovables, the settlor's intent gets less consideration, and situs law is generally applied.180 The privilege of specifying in the dispositive instrument the state law which is to govern not only prevents conflicts problems, but it should also avoid litigation by enabling a lawyer to draft in accordance with a state law on which he is expert and perhaps to select a favorable jurisdiction. Testamentary and inter vivos trusts are normally drafted in accordance with the law of the settlor's domicile at the time of execution; and with regard to their validity, construction, and administration, that law should usually be the specified governing law, unless it is preferred to rely upon the court and conflicts rules.

As to powers of appointment, conflicts problems arise when the donor and donee are not domiciled in the same jurisdiction or when the appointive assets have a situs in a state where neither the donor nor the donee is domiciled. Even if all contacts are with a single state when the power is created, this may not continue. Quite often today, a person is domiciled in one jurisdiction when he makes his will, in another at the time of his death, and a third state is the situs of both movables and immovables owned by him. By traditional rules his testamentary disposal of movables is governed by the

${ }^{178}$ Inter vivos trusts: Wilmington Trust Co. v. Wilmington Trust Co., 26 Del. Ch. 397, 24 A.2d 309 (1942); Shannon v. Irving Trust Co., 275 N.Y. 95,9 N.E.2d 792 (1937); Restatement (Second), Conflict of Laws $\$ 294$, comment $c$ (Tent. Draft No. 5, 1959). Testamentary trusts: Amerige v. Attorney Gen., 324 Mass. 648, 88 N.E.2d 126 (1949); Matter of Tabbagh, 167 Misc. 156, 3 N.Y.S.2d 542 (Surr. Ct. 1938); Matter of Chappell, 124 Wash. 128, 213 Pac. 684 (1923); Restatement (SECOND), Conflict of Laws \& 295 (Tent. Draft No. 5, 1959).

${ }^{270}$ Lewis v. Hanson, 36 Del. Ch. 235, 128 A.2d 819 (1957), aff d, 357 U.S. 235, rehearing denied, 358 U.S. 858 (1958); National Shawmut Bank v. Cumming, 325 Mass. 457, 91 N.E.2d 337 (1950); 4 Powell ๆ 534 (1954); Restatement (SECOND), Conflict of LAws $\& 294$, comment $d$ (Tent. Draft No. 5, 1959).

${ }^{280}$ See Toledo Soc'y for Crippled Children v. Hickok, 152 Tex. 578, 261 S.W.2d 692 (1953); RestateMent (SECOND), Conflict of LAWs $\$ \S 241,249$ (Tent. Draft No. 5, 1959). 
law of his domicile at death ${ }^{181}$ and his immovables by the law of the situs. ${ }^{182}$ Thus, it is always wise to be certain that every will or deed meets the required formalities of all states having a present or prospective contact with the transaction. In addition to the privilege of specifying the applicable state law, some of the more important construction problems may be avoided by cognizance of them and the insertion of provisions to control in either the creation or exercise of the power. For example, problems which are decided on the basis of the intention of the donor or the donee may be explicitly provided for and litigation prevented. Who are the objects of the power is a matter of the donor's intent, and if the objects of the power are "children" or "issue" or "heirs" of a named person, a definitional clause settling the matter may be inserted by the draftsman of the power. ${ }^{183}$ Whether a power is exercised is a matter of the intention of the donee, and a clear intent properly manifested to exercise or not to exercise a power will eliminate this question. Choice of law problems which involve not questions of the intention of the donor or of the donee but rather policy questions such as restraints on alienation or the Rule Against Perpetuities are not so easily handled by specific provision. ${ }^{184}$

Such is the state of uncertainty in the conflicts rules regarding powers of appointment that useful generalization is difficult. ${ }^{185}$ For the estate planner and draftsman, principal legal focuses as to powers of appointment concern their creation and exercise. They are usually created as part of a single conveyance, inter vivos or testa. mentary, which often involves successive estates, legal or equitable, and the same law usually governs the whole transaction, ${ }^{180}$ which, as above stated as to movables, may be specified by the transferor-

\footnotetext{
${ }^{181}$ Second Bank-State St. Trust Co. v. Weston, 342 Mass. 630, 174 N.E.2d 763 (1961); In re Beaumont's Estate, 216 Pa. 350, 65 Atl. 799 (1907); REsTateMent (SECOND), CoNFLICT of Laws $\S 306$ (Tent. Draft No. 5, 1959).

${ }_{182}$ McPherson v. McKay, 207 Ark. 546, 181 S.W.2d 685 (1944); RestatemENT (SECOND), Conflict of Laws $\$ 249$ (Tent. Draft No. 5, 1959).

183 See Casner, Estate Planning 1207-08 (3d ed. 1961), suggesting the form of such a clause.

${ }^{184}$ Id. at 669.771 .

${ }^{185}$ See generally Durand \& Ferterich, Conflict of Laws and the Exercise of Powers of Appointment, 42 CORNELL L.Q. 185 (1957); Ester \& Scoles, supra note 177; Scoles, Conflict of Laws in Estate Planning, 9 U. FLA. L. REv. 398 (1956).

${ }^{18 B}$ Boston Safe Deposit \& Trust Co. v. Prindle, 290 Mass. 577, 195 N.E. 793 (1935); Restatement (Second), Conflict of Laws $\$ 234$ (Tent. Draít No. 5, 1959); id. $\$ 294$, comment g; id. $\$ 295$, comment g; notes 59, 60 supra.
} 
donor. ${ }^{187}$ As to immovables, situs law controls the validity of crea. tion of a power by deed or will.188 As to movables, the same is true for inter vivos creation, ${ }^{189}$ but the law of the donor's domicile appears to control testamentary creation. ${ }^{190}$ As to exercise, situs normally governs the formal validity of an attempted inter vivos appointment of personalty, ${ }^{191}$ and the same is true for either a deed or a will exercising a power of appointment over land.192 Regarding the validity of a testamentary appointment of personalty, it is the general rule that if the will provision is valid under the law of either the domicile of the donee at his death or that of the donor when he executed the instrument creating the power, the appointment is valid. ${ }^{103}$ The basic common law theory of relation back is of much importance in the solution of a conflicts problem when creation and exercise of the power occur in different jurisdictions, and the donee's will exercising a power must generally meet the legal formalities of the donor's state on the theory that the property passes from the donor to the appointee. ${ }^{194}$

Complete and careful drafting of the dispositive instrument which creates the power should usually specify which state law the donor wishes to govern its validity and perhaps should empower the donee to select the state law to govern its exercise by him. Such provisions will likely prevail in the absence of real conflict with local

${ }^{187}$ Lewis v. Hanson, 36 Del. Ch. 235, 128 A.2d 819 (1957), aff'd, 357 U.S. 235, rehearing denied, 358 U.S. 858 (1958); Amerige v. Attorney Gen., 324 Mass. 648, 88 N.E.2d 126 (1949); Matter of Pratt's Trust, 5 App. Div. 2d 501, 1172 N.Y.S.2d 965 (1958), aff'd, 8 N.Y.2d 855, 168 N.E.2d 709, 203 N.Y.S.2d 906 (1960).

${ }^{183}$ Callwood v. Virgin Islands Nat'l Bank, 221 F.2d 770 (3d Cir. 1955); RestateMent (Second), Conflict of Laws $\$ \S 233,234$ (Tent. Draft No. 5, 1959).

${ }^{180}$ Restatement (Second), Conflict of Laws $\$ 253$ (Tent. Draft No. 5, 1959).

${ }^{100}$ Leflar, Conflict of Laws $\$ 190$ (1959); Restatement (Second), Conflict of LAws \$ 295 (Tent. Draft No. 5, 1959); Note, The Testator's Intention as a Factor in Determining the Place of Probate of His Estate, 33 IND. L.J. 591 (1958).

101 Warner v. Florida Bank \& Trust Co., 160 F.2d 766 (5th Cir. 1947); Banque de France v. Chase Nat'l Bank, 60 F.2d 703 (2d Cir. 1932); O'Neil v. O'Neil, 43 Mont. 505, 117 Pac. 889 (1911); Hutchinson v. Ross, 262 N.Y. 381, 187 N.E. 65 (1933); RestateMENT (SECOND), Conflict of Laws $\$ 283$ (Tent. Draft No. 5, 1959).

${ }^{102}$ Liggett v. Fidelity \& Columbia Trust Co., 274 Ky. 387, 118 S.W.2d 720 (1938); Greenough v. Osgood, 235 Mass. 235, 126 N.E. 461 (1920); Matter of Kelley, I6I Misc. 255, 291 N.Y. Supp. 860 (Surr. Ct. 1936); REstatement (SECOND), Conflict of Laws $\$ 234$ (Tent. Draft No. 5, 1959).

${ }^{203}$ Legg's Estate v. Commissioner, 114 F.2d 760 (4th Cir. 1940); Bussing v. Hough, 237 Iowa 194, 21 N.W.2d 587 (1946); Restatement, Conflict of LAws $\$ 287$ (1934).

104 Prince de Bearn v. Winans, $111 \mathrm{Md}$. 434, 74 Atl. 625 (1909); Sewall v. Wilmer, 132 Mass. 131 (1882); Bundy v. United States Trust Co., 257 Mass. 72, 153 N.E. 337 (1926); Fidelity Union Trust Co. v. Caldwell, 137 N.J. Eq. 362; 44 A.2d 842 (Ch. 1945); Matter of Dean, 4 N.Y.2d 326, 151 N.E.2d 184, 175 N.Y.S.2d 21 (1958). 
policy, and frequently even in policy matters. The exercise of a power of appointment by a nonresident donee usually involves the laws of two states. The laws of the states differ in so many particulars that conflicts have arisen and will arise with greater frequency as the increased utilization of powers of appointment makes itself felt.

Recognition that the donee of the power usually has the right to direct that the appointive property shall be administered in the donee's domicile, and also the right to direct that the construction and effect of the exercise of the power and the powers and authority of the trustee to whom the fund is appointed shall be determined by the laws of his domicile, would help estate planners to avoid some of the more important conflicts. ${ }^{195}$

Thus, it seems possible that between them, the draftsman who creates the power and the draftsman who exercises it can eliminate by proper drafting a large part of the area of conflict of laws involving powers of appointment. However, in the matter of specification of governing law, there can be no one rule because of variant fact situations and legitimate differences of opinion by draftsmen. ${ }^{100}$

IX

\section{A Suggested Provision for Powers of Appointment}

The following provision is calculated to settle certain of the principal problems previously mentioned in connection with the creation and exercise of powers of appointment. For convenience of use it is presented in the form of a numbered set of answers to these problems, and it may be adopted, rejected, or altered in whole or in part. Subject to such modifications as may be in order to suit the particular case, the entire provision or parts thereof may be included and made applicable to one, some, or all of the powers created by the dispositive instrument.

Unless otherwise provided, the donee of any power of appointment created by this instrument in its exercise may appoint (I) to any one or more of the objects of the power to the exclusion of other objects; (2) to children or grandchildren even though the parents of such appointees are then living; (3) limited or unlimited interests, present or future, including life estates and remainders; (4) outright or in trust, in which case he may select trustees who need not be objects of the power and confer powers of appointment and such administrative powers as are

${ }^{295}$ Durant \& Herterich, supra note 185, at 207.

190 Shattuck \& FarR, AN Estate PlanNER's HandBook $\$ \$ 54-57$ (2d ed. 1953). 
deemed appropriate upon any trustee selected; (5) subject to such conditions and such lawful spendthrift and other restrictions as may be designated; (6) by creating in any object a general power of appointment or a special power to appoint among objects of the original power; (7) provided no interest, power, or condition shall be created to benefit anyone not an object of the power being exercised.

(8) Any power exercisable by will may be so exercised only by specific reference to it in the donee's will. (9) Any power which is created by will may be exercised by the donee's will, whether such will is executed before or after the date of the donor's death.

(10) All powers created by this instrument are releasable in whole or in part. (11) Any releasable power of appointment or administrative power may be released in whole or in part (a) by a signed instrument in writing, filed either with the trustee of the trust under the terms of which such is created or with any court which has granted probate of the donor's will, or (b) in such other manner as may be provided by law.

(12) These powers of the donee are in addition to, and not in restriction of, powers he would otherwise have.

(13) Under any power of appointment created by this instrument, no person to whom an appointment is made may share in the gift in default of appointment unless he contributes the property appointed to him to the fund to be distributed as in default of appointment.

(14) So far as may be allowable, all questions relating to powers of appointment created by this instrument shall be resolved in accordance with the law of the state of [North Carolina]. ${ }^{196}$

207 See Leach \& Logan, Future Interests \& Estate Planning 976 (1961); StepmensoN $\$ 4.8$; Halbach, The Use of Powers of Appointment in Estate Planning, 45 IowA L. REv. 691,717 (1960). 